\title{
Possible ways of technogenic formations processing with zinc extraction from sulphide compounds
}

\author{
Mikhail Mikheenkov ${ }^{1, *}$, Oleg Sheshukov ${ }^{1,2}$, and Ilya Nekrasov ${ }^{1,2}$ \\ ${ }^{1}$ Federal State Budgetary Institution of Science Institute of Metallurgy of the Ural Branch of the \\ Russian Academy of Sciences, 620016, Ekaterinburg, Amundsen st., 10, Russia \\ ${ }^{2}$ Federal State Autonomous Educational Institution of Higher Education «Ural Federal University \\ named after the first President of Russia B.N.Yeltsin», 620002, Ekaterinburg, Mira st., 19, Russia
}

\begin{abstract}
Extraction of zinc from sulphide forms by pyrometallurgical methods is difficult due to the high energy of the "zinc-sulfur" bond. Theoretically justified and experimentally confirmed the possible methods of extracting zinc from such compounds by changing of raw material phase composition. The zinc oxide obtained by this way has high purity and does not require additional purification by hydrochemical methods.
\end{abstract}

Zinc oxide $(\mathrm{ZnO})$ can be found in the dust of arc steel-smelting furnaces and in the top dust of blast furnaces. To extract oxide forms of zinc Waelz process is used. It carried out in rotary and ring furnaces [1-6]. Under the conditions of the Waelz process, a coal-containing material is added to the raw material mixture, which ensures the reduction of zinc oxide and its sublimation at a temperature of about $1100^{\circ} \mathrm{C}$.

In some technogenic formations, such as sludges from the synthetic fibers production, zinc is present in sulphide form $(\mathrm{ZnS})$. Extraction of zinc from such formations using the Waelz process is difficult.

The Waelz process is based on the reduction of zinc oxide to zinc using carboncontaining material by the reaction 1 . Table 1 shows the Gibbs energy change calculation for reaction 1 as a function of temperature.

$$
2 \mathrm{ZnO}+\mathrm{C}=2 \mathrm{Zn} \uparrow+\mathrm{CO}_{2} \uparrow .
$$

Table 1. Gibbs energy change for the reaction 1

\begin{tabular}{|c|c|c|c|c|c|}
\hline $\mathrm{T},{ }^{\circ} \mathrm{C}$ & 0 & 800 & 900 & 1000 & 1100 \\
\hline$\Delta \mathrm{G}, \mathrm{kJ} / \mathrm{mol}$ & 447 & 104 & 63 & 21 & -18 \\
\hline
\end{tabular}

Thermodynamic calculation results indicate that reaction 1 is possibly above the temperature $1100^{\circ} \mathrm{C}$, when the Gibbs energy change becomes negative. This rule is implemented in the Waelz process. For sublimation of zinc from the oxide form in the presence of carbon, the raw material mixture should be heated above $1100^{\circ} \mathrm{C}$.

\footnotetext{
* Corresponding author: silast@mail.ru
} 
The zinc reduction from sulfide in the presence of carbon will proceed by reaction 2 . Table 1 shows the Gibbs energy change for reaction 1 as a function of temperature.

$$
2 \mathrm{ZnS}+\mathrm{C}=2 \mathrm{Zn} \uparrow+\mathrm{CS}_{2} .
$$

Table 2. Gibbs energy change for the reaction 2

\begin{tabular}{|c|c|c|c|c|c|}
\hline $\mathrm{T},{ }^{\circ} \mathrm{C}$ & 0 & 800 & 900 & 1000 & 1100 \\
\hline$\Delta \mathrm{G}, \mathrm{kJ} / \mathrm{mol}$ & 660 & 376 & 341 & 306 & 271 \\
\hline
\end{tabular}

The thermodynamic calculations show that the reaction 2 is impossible at the temperature of $1100{ }^{\circ} \mathrm{C}$, since the Gibbs energy change does not become negative at this temperature. That reaction could proceed only above the temperature of $1900{ }^{\circ} \mathrm{C}$. To obtain such temperature in practice, it will be necessary to use special high-temperature units (for example, arc furnaces), which are not economically feasible.

Sulfur can be removed by oxygen blowing. Sulfur is removed in the form of $\mathrm{SO}_{2}$ gas, and zinc is converted to the oxide form by the reaction 3 .

$$
2 \mathrm{ZnS}+2 \mathrm{O}_{2}=2 \mathrm{ZnO}+\mathrm{SO}_{2} \uparrow .
$$

When implementing a similar scheme for sulfur removing, zinc remains in the raw material mixture in the oxide form. The sublimation required another step, where zinc oxide would be reduced. For example, after the sulfur removal, carbon-containing material must be introduced into the raw mix to sublimate zinc. This means that this technology is only realizable in two stages, since the carbon-containing material can't be introduced into the raw mix before blowing oxygen, due to it will burned out without restoring zinc oxide.

The exchange reactions realization, with the zinc sulfide form transformation into oxide, is possible with metals that are located in the metal reactivity series higher, than zinc: Li, $\mathrm{K}$, $\mathrm{Ba}, \mathrm{Sr}, \mathrm{Ca}, \mathrm{Na}, \mathrm{Mg}, \mathrm{Al}, \mathrm{Mn}$.

Limestone, magnesite and dolomite are the most suitable for converting zinc sulfide forms to oxide. The limestone is used for the zinc sulfide decomposition and the zinc sublimation is possible by the reaction 4 . This reaction goes through several stages during heat. At the temperature of $720{ }^{\circ} \mathrm{C}$, the limestone decomposition begins by the reaction 5 . The limestone decomposition is completed at a temperature of $920{ }^{\circ} \mathrm{C}$. The exchange reaction 6 proceeds above this temperature.

$$
\begin{gathered}
2 \mathrm{ZnS}+2 \mathrm{CaCO}_{3}+\mathrm{C}=2 \mathrm{Zn} \uparrow+2 \mathrm{CaS}+3 \mathrm{CO}_{2} \uparrow . \\
\mathrm{CaCO}_{3}=\mathrm{CaO}+\mathrm{CO}_{2} . \\
\mathrm{ZnS}+\mathrm{CaO}=\mathrm{CaS}+\mathrm{ZnO} .
\end{gathered}
$$

With zinc oxide appearing carbon begins to interact with it and completes the zinc oxide decomposition by reaction 1 . Table 3 shows the Gibbs energy change calculation of the reaction 4 depending on the temperature.

Table 3. Gibbs energy change for the reaction 4

\begin{tabular}{|c|c|c|c|c|c|}
\hline $\mathrm{T},{ }^{\circ} \mathrm{C}$ & 0 & 800 & 900 & 1000 & 1100 \\
\hline$\Delta \mathrm{G}, \mathrm{kJ} / \mathrm{mol}$ & 742 & 152 & 82 & 12 & -56 \\
\hline
\end{tabular}

The reaction 4 is thermodynamically possible above $1100{ }^{\circ} \mathrm{C}$, at which Gibbs energy change becomes negative. Also, calculations result show that the thermodynamic preference for the 4 reaction at $1100{ }^{\circ} \mathrm{C}$ is 3 times higher than for reaction 1 .

Assessment of the zinc sulfide decomposition possibility was carried out during laboratory experiments. Original material, the sludge from the production of synthetic 
fibers (Balakovo, Saratov region, Russia), was heated up to $1300{ }^{\circ} \mathrm{C}$ in laboratory furnace with additional components. In this sludge, the concentration of zinc sulfide depends on the occurrence depth, therefore the sludge average chemical composition is shown in Table 4. The sludge phase composition is shown in Table 5.

Table 4. The average chemical composition of the sludge.

\begin{tabular}{|c|c|c|c|c|c|c|c|}
\hline Component & $\mathrm{CaO}$ & $\mathrm{SiO}_{2}$ & $\mathrm{Al}_{2} \mathrm{O}_{3}$ & $\mathrm{Fe}_{2} \mathrm{O}_{3}$ & $\mathrm{ZnS}$ & $\mathrm{SO}_{3}$ & Ост. \\
\hline mass. \% & 20,4 & 9,1 & 3,6 & 2,5 & 22,7 & 32,6 & 9,1 \\
\hline
\end{tabular}

Table 5. The sludge phase composition.

\begin{tabular}{|l|c|c|}
\hline \multicolumn{1}{|c|}{ Phase name } & Chemical formula & Content, mass. \% \\
\hline Calcite (limestone) & $\mathrm{CaCO}_{3}$ & 55,41 \\
\hline Gypsum dihydrate & $\mathrm{CaSO}_{4} \cdot 2 \mathrm{H}_{2} \mathrm{O}$ & 18,24 \\
\hline Zinc sulfide & $\mathrm{ZnS}$ & 12,77 \\
\hline Quartz & $\mathrm{SiO}_{2}$ & 13,58 \\
\hline \multicolumn{2}{|c|}{ Total } & 100,00 \\
\hline
\end{tabular}

The phase analysis data show that the sludge, in addition to zinc sulfide, contains a significant amount of limestone, which will contribute to the decomposition of zinc sulfide by reaction 4 . The calculation of reaction 4 stoichiometry showed that in order to fully realize it, only a small amount of limestone should be added. The mixture composition for the firing implementation is shown in table 6

Table 6. The mixture composition.

\begin{tabular}{|c|c|c|c|}
\hline Material & Sludge & $\mathrm{CaCO}_{3}$ & $\mathrm{C}$ (above 100 mass.\%) \\
\hline mass. \% & 98,0 & 2,0 & 3,0 \\
\hline
\end{tabular}

Raw mix components were homogenized by co-grinding and briquetted with water added at a pressure of $50 \mathrm{MPa}$. Briquettes were fired at temperatures of 1100,1200 and $1300{ }^{\circ} \mathrm{C}$ without isothermal exposure. The firing was carried out in the laboratory hightemperature electric chamber furnace brand SKV 12/14-B. Fired samples were subjected to quantitative phase analysis. Table 7-9 shows the sample phase compositions, fired at 1100 , 1200 and $1300{ }^{\circ} \mathrm{C}$ accordingly. Table 10 shows summary results on the zinc phases content in the samples at the realized firing temperatures.

Table 7. The sample phase composition, fired at $1100^{\circ} \mathrm{C}$

\begin{tabular}{|l|c|c|}
\hline \multicolumn{1}{|c|}{ Phase name } & Chemical formula & Content, mass. \% \\
\hline Helenite & $2 \mathrm{CaO} \cdot \mathrm{SiO}_{2} \cdot \mathrm{Al}_{2} \mathrm{O}_{3}$ & 23,50 \\
\hline Zinc sulfide & $\mathrm{ZnS}$ & 15,3 \\
\hline Mayenite & $12 \mathrm{CaO} \cdot 7 \mathrm{Al}_{2} \mathrm{O}_{3}$ & 6,75 \\
\hline Zinc Oxide (Zincite) & $\mathrm{ZnO}$ & 9,27 \\
\hline Larnit & $2 \mathrm{CaO} \cdot \mathrm{SiO}_{2}$ & 22,07 \\
\hline Gypsum anhydrite & $\mathrm{CaSO}$ & 9,11 \\
\hline Zinc Sulfide Oxide (Wurtzite) & $\mathrm{Zn}\left(\mathrm{S}_{0,988} \mathrm{O}_{0,12}\right)$ & 14,0 \\
\hline \multicolumn{2}{|c|}{ Total } & 100 \\
\hline
\end{tabular}


Table 8. The sample phase composition, fired at $1200^{\circ} \mathrm{C}$.

\begin{tabular}{|l|c|c|}
\hline \multicolumn{1}{|c|}{ Phase name } & Chemical formula & Content, mass. \% \\
\hline Larnit & $2 \mathrm{CaO} \cdot \mathrm{SiO}_{2}$ & 31,94 \\
\hline Zinc sulfide & $\mathrm{ZnS}$ & 10,06 \\
\hline Helenite & $2 \mathrm{CaO} \cdot \mathrm{SiO} 2 \cdot \mathrm{Al}_{2} \mathrm{O}_{3}$ & 16,52 \\
\hline Gypsum anhydrite & $\mathrm{CaSO}$ & 10,51 \\
\hline Zinc Oxide (Zincite) & $\mathrm{ZnO}$ & 14,76 \\
\hline Mayenite & $12 \mathrm{CaO} \cdot 7 \mathrm{Al}_{2} \mathrm{O}_{3}$ & 6,71 \\
\hline Zinc Sulfide Oxide (Wurtzite) & $\mathrm{Zn}\left(\mathrm{S}_{0,988} \mathrm{O}_{0,12}\right)$ & 9,5 \\
\hline \multicolumn{2}{|c|}{ Total } & 100 \\
\hline
\end{tabular}

Table 9. The sample phase composition, fired at $1300^{\circ} \mathrm{C}$.

\begin{tabular}{|c|c|c|}
\hline Phase name & Chemical formula & Content, mass. $\%$ \\
\hline Larnit & $2 \mathrm{CaO} \cdot \mathrm{SiO}_{2}$ & 32,38 \\
\hline Zinc sulfide & $\mathrm{ZnS}$ & 6,87 \\
\hline Helenite & $2 \mathrm{CaO} \cdot \mathrm{SiO}_{2} \cdot \mathrm{Al}_{2} \mathrm{O}_{3}$ & 9,26 \\
\hline Calcium Olivine & $2 \mathrm{CaO} \cdot \mathrm{SiO}_{2}$ & 11,32 \\
\hline Zinc Oxide (Zincite) & $\mathrm{ZnO}$ & 17,56 \\
\hline Highly basic calcium ferrite & $2 \mathrm{CaO} \cdot \mathrm{Fe}_{2} \mathrm{O}_{3}$ & 7,9 \\
\hline Mayenite & $12 \mathrm{CaO} \cdot 7 \mathrm{Al}_{2} \mathrm{O}_{3}$ & 6,22 \\
\hline Zinc Sulfide Oxide (Wurtzite) & $\mathrm{Zn}\left(\mathrm{S}_{0,988} \mathrm{O}_{0,12}\right)$ & 4,28 \\
\hline Zinc Sulfide Hydroxide & $\mathrm{ZnSO}_{4} \cdot 3 \mathrm{Zn}\left(\mathrm{O} \mathrm{H}_{2} \cdot 3 \mathrm{H}_{2} \mathrm{O}\right.$ & 1,42 \\
\hline Gypsum anhydrite & $\mathrm{CaSO}_{4}$ & 2,77 \\
\hline \multicolumn{2}{|c|}{ Total } & 99.98 \\
\hline
\end{tabular}

Table 10. The zinc phase content changes with firing temperature.

\begin{tabular}{|c|c|c|c|c|}
\hline \multirow{2}{*}{$\mathrm{T},{ }^{\circ} \mathrm{C}$} & \multicolumn{3}{|c|}{ Content, mass. \% } & \multirow{2}{*}{ Zinc sublimate, mass. \% } \\
\cline { 2 - 4 } & $\mathrm{ZnS}$ & $\mathrm{ZnO}$ & $\mathrm{ZnS}+\mathrm{ZnO}$ & \\
\hline 0 & 34,4 & 0 & 34,4 & 0 \\
\hline 1100 & 15,3 & 9,3 & 24,6 & 9,8 \\
\hline 1200 & 10,0 & 14,8 & 24,8 & 9,6 \\
\hline 1300 & 6,87 & 17,6 & 24,5 & 9,93 \\
\hline
\end{tabular}

The firing products phase analysis results listed in Table 10 indicate that with an increase in the firing temperature, the amount of zinc sulfide in samples decreases and zinc oxide increases. That indicates the theoretical conclusions correctness and the feasibility of the proposed technology.

The reported study was funded by RFBR according to the research project № 18-29-24064 \18.

\section{References}

1. P.A. Kozlov, A.M. Panshin, V.G. Dyubanov, E.N. Selivanov, Development and industrial implementation of integrated and resource- energy-saving technologies and equipment for the processing of industrial wastes from ferrous and nonferrous metallurgy with the extraction of zinc, lead, tin, copper and iron into commercial products, Proceedings of the scientific and practical conference with international participation "Prospects for the development of metallurgy and engineering with the 
use of completed basic research and research and development ", Yekaterinburg, pp.29-32 (2015)

2. J.M. McClelland, G.E. Metius, Recycling Ferrous \& Nonferrous Waste Streams with FASTMET, J. of the Minerals, Metals \& Materials Society, № 8, pp. 30-34 (2003)

3. Ma. Naiyang, Recycling of basic oxygen furnace steelmaking dust by in process separation of zinc from the dust, Journal of Cleaner Production 112, pp 4497-4504 (2016)

4. L.M. Axelrod, V.A. Maltsev, S.G. Melamud, A.P. Baranov, Ecological and other problems of processing zinc-containing dusts from arc steel-smelting furnaces, Ferrous metallurgy, №7 (1351), pp.91-96 (2012)

5. A.P. Baranov, I.B. Fedosov, N.V. Tleukhov, A. Woolett, Bee P. Wynter, The practice of processing zinc-containing electrometallurgical steel dust using the latest technology of the British company Zincox Resources Pls in the Republic of Korea. Ferrous metallurgy, No. 11 (1379), pp. $71-76$ (2014)

6. P.I. Grudinsky, V.G. Dyubanov, L.I. Leontyev, P.A. Kozlov, Investigation of the zinc ferrite decomposition process during the calcination of electric steel melting dust in the presence of lime. Proceedings of the Congress with international participation and the Conference of Young Scientists, V Forum "Fundamental research and applied development of processes for processing and recycling technogenic formations. Ural market of scrap, industrial and municipal waste". Publisher: Federal State Budgetary Institution of Science Institute of Metallurgy of the Ural Branch of the Russian Academy of Sciences (Yekaterinburg), pp.182-184. (2017) 